Christa Lykke Christensen, lektor, Institut for Medier, Erkendelse og Formidling, Københavns Universitet, christal@hum.ku.dk

\title{
Er web- og tv-serien SKAM en serie om skam?
}

\begin{abstract}
In this article, I discuss whether the Norwegian teen web series drama SKAM (NRK, 2015-2017) is really about shame and to what extent the fictional characters of the series feel ashamed. The theoretical framework is based on a social psychological conceptualization of shame, supplemented by a micro-sociologically based analysis of the social meaning of face loss and shame. Shame may both entail a negative feeling and an active mechanism serving social and psychological purposes. The main characters of the series are used to analytically exemplify the role of shame and embarrassment. In conclusion, the series does thematize shame and the characters are often placed in conflicts that may give rise to shame. On the other hand, the series also suggests potential social strategies, to constructively avoid the face loss of shameful situations.
\end{abstract}

Keywords: skam, tv-/web-serie, ungdoms-tv, ansigt, følelser, pinlighed

\section{Introduktion}

Er der i den norske web- og tv-serie SKAM noget, som i særlig grad kan berettige seriens titel? Serien omhandler unge gymnasieelever, der befinder sig i en identitetsmæssigt udfordrende livsfase, hvor både forelskelse, ulykkelig kærlighed, misforståelser og svigt giver anledning til følelsesmæssige rutsjeture. Men tematiserer serien følelsen skam, og skammer de sig egentlig i SKAM?

Dette spørgsmål vil i det følgende blive belyst, dels ved hjælp af forskellige teoretiske vinkler på fænomenet skam, dels ved analytiske iagttagelser af, hvordan først og fremmest SKAM's centrale karakterer - Eva, Noora, Vilde, Isak og Sana - der er bærere af de enkelte sæsoners hovedkonflikter, tackler situationer, som kan diskuteres i lyset af fænomenet skam. Teoretisk tager artiklen sit afsæt i en social-psykologisk forståelse af skam og skamfølelse og vil på baggrund af en mikro-sociologisk funderet analyse af ansigtstabets og skammens sociale betydning, fokusere på fænomenet skam som både en negativ følelse og som en socialt virksom mekanisme, der kan tjene såvel sociale som psykologiske formål. En udfoldet analyse af seriens enkelte karakterer er ikke formålet med artiklen; derimod vil de respektive karakterer blive inddraget som eksempler, der skal tjene den teoretiske diskussion af skam og skammens betydning. Det er på denne baggrund, at artiklen vil diskutere, hvorvidt og i givet fald hvordan serien forholder sig til sin titel. 


\section{Skam som negativ selvfølelse}

Set i et psykologisk perspektiv peger forskere på, at skam tilhører menneskets selvbevidste følelser (Lewis, 1995; Skårderud, 2006; Tangney \& Fischer, 1995; Tangney \& Tracy, 2011). Det betyder, "at vi reflekterer over og tar stilling til vårt psykologiske og sociale selv, over hvem vi er og hvem vi vil være. (...) Skammen repræsenterer en selviakttakelse..." samt det forhold "å se seg selv med de andres blikk" (Skårderud 2006, s. 49). På den ene side er skamfølelsen altså en følelse, der opleves og føles yderst personlig. På den anden side er skamfølelsen knyttet til selve det sociale forhold mennesker imellem og til, hvordan andre opleves at vurdere én selv. Skam er derfor både et individuelt-psykologisk og et socialt og kulturelt fænomen.

Skamfølelsen kan have sin oprindelse i forskellige instanser eller situationer. Den kan være aff $\varnothing \mathrm{dt}$ af de normer, der kulturelt gør sig gældende for, hvornår man bør føle sig skamfuld, fx kan den afklædte, nøgne krop i bestemte situationer opleves som behæftet med skam. Skamfølelsen kan også være foranlediget af andre mennesker, $\mathrm{fx}$ som følge af krænkende bemærkninger og adfærd. I SKAM er det fx tilfældet med Noora, der skammer sig over, at en anden, Nicolai, muligvis har lagt et nøgenbillede af hende på internettet. Hun står i fare for at blive konfronteret med et blik på sig selv udefra, som hun ikke kan acceptere, da hun ikke selv har foranlediget denne eksponering - eller i tilfældet med Eva, der ønsker at forsone sig med Ingrid og fortæller hende, at hun savner hende, men brutalt bliver afvist med den, for sagen uvedkommende, sårende bemærkning fra Ingrid om Eva's udseende: "Du ser ut som en slut" (SKAM, sæson 1).

Skamfølelsen kan også stamme fra en konstant følelse af underlegenhed i bestemte situationer, hvor den negative selviagttagelse får en sådan vægt, at den bliver socialt lammende. Dette kunne - uden at serien dog helt overbeviser os om det - være tilfældet med karakteren Linn, idet hun - helt frem til Sanas fest i fjerde sæson, hvor hun møder op iklædt hijab - skildres som en ikke kun sløv og ugidelig, men også altid stille og trist person, der tilsyneladende 'vælger' at stå uden for de øvrige personers fællesskab. Uanset i hvilke situationer skamfølelsen opstår og hvem der rammes af den, opleves den som en udelukkende negativ følelse, der "encompasses the whole of ourselves; it generates a wish to hide, to disappear, or even to die" (Lewis 1995, p. 2).

\section{Ansigtstab}

I et sociologisk perspektiv sætter Erving Goffman (2004) fokus på skam og pinlighed som reguleringsmekanismer, der kan tjene sociale funktioner. Han understreger det situationsbestemte i forbindelse med sådanne følelser og forklarer skam som en følelse, der kan opstå som følge af at tabe ansigt og i desto højere grad, hvis andre opdager dette ansigtstab (Goffman 2004, s. 42). Ansigtstab er at $\varnothing$ le andres ikke- $\varnothing$ nskede blik på sig med den konsekvens, at den sociale situation, man er del af, står i fare for at blive destabiliseret, frem for bekræftet og opretholdt (Op.cit., s. 45). Ansigtstab og skamfølelse giver sig ofte udslag i en tilbagetrækning som følge af, hvad også Skårderud (2006, s. 49) påpeger, at man ikke kan leve op til forventningerne til én selv, og man dermed ikke kan blive $m \varnothing d t$ af det blik fra andre, man gerne vil mødes af. Skammen resulterer derfor ofte i tilbagetrækning, i tavshed og ønsket om at kunne forsvinde og krybe i et musehul.

Oplagte eksempler fra SKAM på et sådant reaktionsmønster er Vilde, da hun i første sæson afvises af William, som hun er forelsket i, med hans lammende bemærkning om, at hun på ingen måde skal tro, at hun er lækker nok til at være hans trofæ (SKAM, sæson 1); eller Sana, der i fjerde sæson indser, hvilke fatale følger hendes oprettelse af den falske Instagram-konto har og som isolerer sig på sit værelse og græmmes. Hvor Sana således skammer sig over at have forvoldt andre skade, forholder det sig omvendt i forbindelse med Noora, da hun bliver offer for Nikolais trusler om at ville offentligg øre et foto af hende (SKAM, sæson 2). Noora bliver ikke, i samme grad som hendes kæreste, William, vred på Nikolai, men krænket og flov. Hun taler ikke med nogen om episoden, da hun oplever at have lidt et afgørende ansigtstab - på trods af, at det er Nikolai, der er skadevolderen, som har opført sig skamløst over for hende. Noora kan således hverken bære at tabe ansigt eller at blive set som bærer af et nyt (og krænket) ansigt - og hun isolerer sig. 
Begrebet om ansigt er, ifølge Goffman, et udtryk for, hvorvidt man er i stand til at bekræfte sig selv i den rolle, man har påtaget sig (Goffman 2004, s. 39). Man kan derfor, som det også er Goffmans pointe, opfatte selve bevidstheden om, at skamfølelse kan indfinde sig som en gunstig social reguleringsmekanisme. Den kan $\mathrm{fx}$ afholde os fra at komme ud i pinlige situationer samt medvirke til, at vi beskytter andre imod, at de kommer ud i sådanne situationer. I den forstand kan skam-bevidstheden 'redde' den sociale sammenhæng fra et sammenbrud. I SKAM er denne mekanisme virksom, omend ikke decideret synlig, da den bl.a. træder i kraft i måden, hvorpå de fem kvindelige hovedkarakterer beskytter hinanden i socialt udfordrende situationer, ved fx ikke at udstille eller grine hånligt af hinanden, men ved at foretage handlinger, der bryder skammens sociale 'logik', eksempelvis som da pigegruppen i fjerde sæson pludseligt kommer kørende i en gammel bus og 'redder' Sana ud af en prekær situation og dermed viser hende både accept og tilgivelse.

Goffman redegør imidlertid også for, hvordan man, i samme grad som man kan 'besidde et ansigt', altså opretholde positiv værdi i et givent socialt møde, kan 'besidde et forkert ansigt', hvor man altså er skæv i forhold den forventede udfyldelse af en given social rolle (Op.cit., s. 41). Man kan med andre ord gøre sig forkerte forestillinger om den sociale rolle, der kræves af én i situationen, og dermed risikere at tabe ansigt. Et eksempel på dette kunne være karakteren Isak, der i de første to sæsoner er meget opmærksom på ikke at komme til at være bærer af 'et forkert ansigt'. Det er sandsynligt, at Isak, indtil han kommer ud af skabet, oplever, at han i kraft af sin homoseksualitet besidder et forkert ansigt, hvilket resulterer $\mathrm{i}$, at han, det bedste han har lært, forsøger at leve op til det ansigt og de normer, han finder virksomme i relation til heteroseksuel adfærd - bl.a. ved at have en kvindelig kæreste og ved at tale nedsættende om bøsser. Han kommer derved til at overkompensere den mangel, han føler, eller det forkerte ansigt han oplever at have $i$ en række sociale situationer. Men hermed undgår han netop at komme ud i pinlige situationer, der kunne destabilisere hans sociale relationer til kammeraterne, hvilket er en situation, han endnu ikke er parat til at skulle konfronteres med. Isak fremstår derfor som en karakter, der har en dyb indsigt i skammens sociale dynamik som en social reguleringsmekanisme, der kan beskytte ham, og som han kan benytte sig af, indtil han oplever, at han kan træde frem med sit oprigtige ansigt uden at risikere at tabe det, så at sige.

Et andet eksempel på 'besiddelsen af et forkert ansigt' kunne være Vilde, der i mange tilfælde 'overspiller' sin rolle som organisator af russebus-projektet. Hun forekommer de andre at være for aktiv og engageret og rammes af de andres initiativløshed, når de ikke bekræfter hende i, hvor vigtig hun er i sin rolle som organisator. Dermed får hun ikke bekræftet det ansigt eller det billede, hun gerne vil have af sig selv som den, der har tjek på tingene og alt under kontrol; situationen tangerer til tider det pinlige, hun 'klapper i', bliver flov og tavs.

\section{Klassisk og moderne skam}

SKAM-serien er således rig på konfliktsituationer, hvor trusler om ansigtstab og efterfølgende skamfuldhed opleves som nærværende for flere af seriens karakterer. Hvor sådanne situationer udspilles i det intense sociale samspil de unge imellem, og af karaktererne opleves på et psykologisk og mikro-sociologisk niveau, gør der sig imidlertid også en 'skam-faktor' gældende på et andet niveau, der i højere grad knytter sig til en historisk og kulturel forståelse af skam.

I den forbindelse taler teologen Trygve Wyller om hhv. en klassisk og moderne form for skam (Wyller 2001, s. 10). Den klassiske skam hører til traditionelt organiserede samfund, hvor faste normer, stærke sociale bånd og tydelige forventninger til acceptabel adfærd markerer skarpe grænser for den individuelle adfærd. Overtrædes sådanne grænser til fordel for forfølgelsen af personlige mål og gevinster, vil det ofte være behæftet med skam, for dermed forbryder man sig mod fælles koder, der holder gruppen, familien og samfundet sammen. Den moderne forståelse af skam er derimod, iflg. Wyller, karakteriseret ved, at man ikke skal skamme sig, da det enkelte menneske tager vare på sig selv og forventes at fastsætte sin egen individuelle dagsorden og sine egne grænser og dermed ikke er underlagt autoritære regler, der kan udløse skam, hvis ikke de overholdes (Ibid.). I SKAM fremstilles karakteren Sana som en pige, der står i et vadested mellem på den ene side de trygge, hjemlige rammer med familien som en fast bastion - og på den anden side hendes gymnasievenner, der omvendt fremstilles som selvberoende individer, hvor familierelationer er stort set fraværende og kun har en minimal 
betydning. Sana fremstilles dog ikke som en person, der kæmper med skamfølelse, bortset fra episoden i fjerde sæson, hvor hun forsøger at hævne sig ud af sine problemer. Hun fremstilles derimod som en pige, der måske nok har andre grænser at tage hensyn til, end vennerne har, men som netop træder i karakter ved ikke at acceptere skammens 'logik' og derfor nægter at være tavs eller tilbageholdende.

\section{At realisere sig selv for lidt}

At man ikke skal skamme sig i den moderne individorienterede verden, betyder imidlertid ikke, at folk ikke skammer sig. Pointen er, at folk stadig skammer sig, men at grundlaget for skamfølelsen har ændret sig i forhold til tidligere. I karakteristikken af den moderne skam henter Wyller (2001) sin argumentation fra modernitetens fokus på selvrealisering og de mange mulige valg, som i sig selv stiller krav til den enkelte om at realisere sig selv på så mange parametre som muligt og om at overskride grænser og ikke lade sig holde tilbage af, hvad evt. normer i kultur og samfund måtte tilsige. I den forstand kunne man sige, at den moderne skam er forbundet med skammen over ikke at kunne vælge, over ikke at være tilstrækkeligt selvstændig og unik i sine mange valg og over ikke "å være autonom nok, for ikke å ha realisert seg selv like mye som 'alle andre'" (Wyller 2001, s.11). I den klassiske skam skammer man sig, hvis man realiserer sig selv for meget; i den moderne skam skammer man sig derimod, hvis man ikke formår at indfri alle de forventninger og muligheder, der stilles i udsigt, og man derfor oplever, at man realiserer sig selv for lidt.

Sociologen Ola Stafseng (2001) beskæftiger sig med samme problematik i et specifikt ungdomspædagogisk perspektiv, hvilket er særligt relevant i relation til en ungdomsfiktionsserie som SKAM. Hans argument er, at med udviklingen af det moderne syn på unge som nogle, der har ret til og skal have mulighed for selvbestemmelse og selvudvikling, samt med nedbrydningen af traditionelle samfundsstrukturer forsvinder gradvist den klassiske skam. Han ræsonnerer, at hvis vi i dag skal tale om skam, "må det være knyttet til det å mislykkes med det subjektive grepet om egensocialiseringen" (Stafseng 2001, s. 31). Stafseng peger på de unge som dem, der især er 'ramt' af selvrealiseringens dilemmaer og i en sådan grad, at de har vanskeligt ved at vide, hvilke pejlemærker det er relevant og godt at have for egen udvikling og identitet. De af traditionen overleverede idealer for livsførelse og udvikling er nok væk, men til gengæld erstattet af et væld af muligheder og idealer, de unge kan forsøge at efterleve, men som de også kan mislykkes med - for hvilke er de bedste, og ud fra hvilke kriterier skal de vælge?

Oplevelsen af de grænseløst mange muligheder kan opleves som en individuel byrde, der også er med til at ændre de situationer, der knyttes til skam. Naturligvis kan skam fortsat opstå i forbindelse med overskridelsen af grænser, ved erfaringen af skamløs og krænkende adfærd, men som Vetlesen (2006) er inde på, er skammens historisk nye skikkelse forbundet med at føle skam over, at grænser overhovedet findes. For "Grensene utfordrer vår streben etter uavhengighet, selvstendighet, mestring, kontroll - kort sagt, det som er grunnelementene i en psykologisk individualisme fiksert på frihet, frihet forstått som den enkeltes valgfrihet. Når valgfriheten - eller budskapet om dens plass i tilværelsen - blir total, slår den over i sin motsettning: valgtvang (Vetlesen 2006, s. 152). Står de unge i fare for at miste orienteringen og grebet om deres eget liv, er det således ikke, fordi de ikke oplever grænser, hvad de naturligvis gør, men fordi de oplever, at grænser altid skal overskrides og nye 'territorier' bør erobres. Ser man sig af forskellige årsager ikke i stand til at være med på den vogn, er der risiko for, at man vil føle sig mislykket, have ringe selvværd og måske være ramt af skamfølelse over ikke at kunne præstere som forventeligt.

\section{Skammer de sig i SKAM?}

Skal vi på baggrund af disse refleksioner over skam besvare spørgsmålet, om de skammer sig i SKAM, vil svaret være et 'ja, men de kæmper med ikke at ville skamme sig'. Seriens prioriterede fokus på sociale relationer mellem de unge fremmer nærmest af sig selv en opmærksomhed på karakterernes manøvrer i ofte konfliktfyldte situationer, hvor skamfølelsen er nærliggende. De unge har travlt med at realisere sig selv, primært i forhold til venner, kærester, sex og alkohol. Især fremstilles festerne som et eksperimenterende rum for denne selvrealisering. Det anskueliggøres bl.a. i introen til 2. sæson. Her præsenteres seeren for hurtigt skiftende billeder fra fester, der ser ud til at være gået ud af kontrol; alle kropslige grænser overskrides, kroppen stilles 
frem og krænges ud, og alle ser ud til at udleve sig selv hundrede procent autentisk i en ekstremt kropslig udadvendt adfærd. Her sættes alle sejl til i forhold til de unges vilde forestillinger om, hvad det vil sige at realisere sig selv og være en autentisk person. Her skammer de sig ikke over at overskride egne grænser eller opføre sig skamløst udfordrende i forhold til andres grænser, for her konstrueres ideelt set et rum, hvor grænser er fraværende, hvor den enkelte forfølger sine helt egne mål og hvor risikoen for ansigtstab i situationen (men ikke nødvendigvis efterfølgende) kan opleves som mindre. Formår man imidlertid ikke at leve op til krav om en sådan forestillet autentisk selvrealisering, kan den oplevelse være nærliggende, at man underpræsterer og føler sig mislykket. Det kunne være Vildes situation, hvorfor hun overkompenserer sine oplevede mangler ved en vældig ekstrovert adfærd.

I et radiointerview er højskolelærer, Christian Hjortkær (Hjortkær 2017) inde på, at unge mennesker nemt kan komme til at opleve sig som altid værende bagud på points. De gør ikke nødvendigvis noget forkert, men "de oplever på den anden side aldrig, at de er helt deroppe, hvor de mener, at de som minimum bør være" (Hjortkær 2017). Ikke at kunne leve op til alle idealer, ikke at kunne udnytte alle de muligheder, der tilbyder sig, repræsenterer ifølge Hjortkær en form for underskudslogik. På den baggrund vil det være nærliggende at $f \varnothing l e$ sig ramt af et kritisk blik, man ikke ønsker sig set af - et blik, som ikke nødvendigvis er andres blik på én selv, men ens eget selvkritiske blik. Dette blik kan udløse følelsen af ikke at slå til over for sig selv, et svigt, der kan ledsages af skam.

Udfra et sådant ræsonnement betragtes skamfølelse og ansigtstab som del af unges erfaring i al almindelighed. I SKAM-serien skildres erfaringen imidlertid ikke særlig eksplicit, hvorimod angsten for prekære og pinlige situationer og for de negative følelser knyttet til skam er mere fremtrædende. Denne angst eller agtpågivenhed i sociale situationer afslører sig ikke mindst i de talrige tavse passager, serien installerer mellem personerne. Her kommer seerne i lange nærbilled-sekvenser tæt på personerne og får indtryk af, at de reflekterer og forhandler med sig selv i forhold til det, som sker omkring dem. Personerne skildres således ikke kun som handlekraftige, impulsive og energiske unge mennesker med fuld fart fremad. De fremstilles som unge, der også eftertænksomt overvejer deres situation og sociale positioner og muligheder - hvilket også levner seerne et udvidet spillerum for eftertanke.

I lyset af en serie som SKAM må man give Goffman ret, når han argumenterer for det socialt virksomme potentiale, der knytter sig til den opmærksomhed, der er omkring selve risikoen for at ende i en skamfuld situation. For serien lykkes overvældende godt med at skildre en ungdomsgruppes fors $\varnothing \mathrm{g}$ på at manøvrere og etablere sig socialt under forhold, hvor de hver især bliver spændt ud imellem på den ene side at skulle realisere deres muligheder fuldt ud, være unikke og autentiske, og på den anden side at ville skabe holdbare, sociale fællesskaber. Det sidste kræver, at de gør sig afhængigheden af andre og af det sociale klart og dermed også forpligter sig til det fælles ansigtsarbejde, der ligger i at beskytte hinanden - og dermed sig selv - for pinlige situationer og dermed også for skammen.

Måske ligger seriens store attraktion i netop det forhold, at gruppens dynamik og hensynet til den sociale situation så entydigt prioriteres til fordel for et fokus på det enkelte individ, der blot skal klare sig bedst muligt og ofte på andres bekostning. I en vis forstand kunne man sige, at i denne serie skildres den enkelte persons særskilte og subjektive $\emptyset$ nsker som mindre vigtige - ja, disse er for så vidt ikke i sig selv særligt interessante. Derimod lykkes det serien at vise, hvordan alle personer skabes og agerer i kraft af gensidige sociale behov. Netop herved lykkes det SKAM at fremstille et socialt fællesskab, der kan rumme de enkelte unge og tilmed rumme dem i al deres forskellighed. De søger anerkendelse hos hinanden på kryds og tværs; de ved, at de er afhængige af hinanden, og at det sociale og fællesskabet rummer værdier, som de ikke vil eller kan leve foruden. Serien kan således, på trods af store konflikter og følelsesmæssige dramaer personerne imellem, betragtes som et billede på, hvordan fænomenet skam ikke kan benægtes, men kan holdes i skak af netop de sociale bånd i det fællesskab, de unge får skabt og som viser sig at være langt større end dem alle sammen tilsammen. 


\section{Referencer}

Goffman, E. (2004 [1967]). Om ansigtsarbejde. I M. H. Jacobsen \& S. Kristiansen (red.), Erving Goffman. Social samhandling og mikrosociologi (pp.39-75). København: Hans Reitzels Forlag.

Hjortkær, C. (2017). Synd, skam og selvrealisering. I Mennesker og Tro, DR Radio P1, 24. maj, kl. 13.00-13.30. Lokaliseret på: http://www.dr.dk/p1/mennesker-og-tro/mennesker-og-tro-christian-hjortkjaer-om-synd-skamog-selvrealisering

Lewis, M. (1995). Shame. The exposed self. New York: Free Press.

Skårderud, F. (2006). Flukten til kroppen - senmoderne skamfortellinger. In P. Gulbrandsen, P. Fugelli, G. H. Stang \& B. Wilmar (Eds.), Skam i det medisinske rom (pp. 45-64). Oslo: Gyldendal.

Stafseng, O. (2001). Ungdommen, skammen og pedagogikken. En kunnskapshistorisk riss om skam og socialiseringsidealer. In T. Wyller (Ed.). Skam. Perspektiver på skam, ære og skamløshet i det moderne (pp. 1935). Bergen: Fagbokforlaget.

Tangney, J. P. \& Fischer, K. W. (1995). Self-conscious emotions. The psychology of shame, guilt, embarrassment, and pride. New York: Guilford Press.

Tangney, J. P. \& Tracy, J. L. (2011). Self-conscious emotions. In M. R. Leary \& J. P. Tangney (Eds.), Handbook of self and identity (pp. 446-479). New York: Guilford Press.

Vetlesen, A. J. (2006). Skam: Fra naturgitt til valgstyrt?. In P. Gulbrandsen, P. Fugelli, G. H. Stang \& B. Wilmar (Eds.). Skam i det medisinske rom. Oslo: Gyldendal Norsk Forlag.

Wyller, T. (2001). Skam, verdighet, grenser. In T. Wyller (Ed.), Skam. Perspektiver på skam, ære og skamløshet i det moderne (pp. 9-18). Bergen: Fagbokforlaget. 